\title{
High genetic differentiation with no evidence of hybridisation between four limpet species (Patella spp.) revealed by allozyme loci
}

\author{
ALEXANDRA SÁ-PINTO ${ }^{1}$, PAULO ALEXANDRINO ${ }^{1,2}$ and MADALENA BRANCO ${ }^{1}$ \\ ${ }^{1}$ Centro de Investigação em Biodiversidade e Recursos Genéticos (CIBIO/UP), Campus Agrário de Vairão, \\ 4485-661 Vairão, Portugal. E-mail: xanasapinto@ mail.icav.up.pt \\ ${ }^{2}$ Departamento de Zoologia-Antropologia, Faculdade de Ciências da Universidade do Porto, 4099-002 Porto, Portugal.
}

\begin{abstract}
SUMMARY: The occurrence of hybridisation between limpet species of the genus Patella has always been a contentious issue. Although a previous allozyme study reported high differentiation and no hybridisation between Patella vulgata Linnaeus, 1758, Patella depressa Pennant, 1777 and Patella ulyssiponensis Gmelin, 1791 along English shores, the recent finding of an mtDNA haplotype of $P$. depressa in a $P$. vulgata individual raised new doubts on this issue. To further study the possibility of hybridisation between limpet species and their level of genetic differentiation, ten allozyme loci were screened using starch gel electrophoresis for P. ulyssiponensis, P. depressa, P. vulgata and Patella rustica Linnaeus, 1758, from the Atlantic coast of the Iberian Peninsula. Our results show high differentiation between species, which could be clearly separated into different clusters with a Bayesian clustering algorithm. No significant signs of hybridisation were detected between any of the four species. Thus, the hypothesis of hybridisation between $P$. vulgata and $P$. depressa across their sympatric distribution is not supported. Two sympatric clusters were recovered within $P$. vulgata that could be related to HardyWeinberg disequilibrium found in locus MPI. Finally, due to the high level of intraspecific variability, the studied loci are interesting tools for the analysis of population structure and stock identification.
\end{abstract}

Keywords: Patellidae, Patella spp., starch gel electrophoresis, allozymes, hybridisation, genetic polymorphism.

RESUMEN: ELEVADA DIFERENCIACIÓN GENÉTICA Y AUSENCIA DE HIBRIDACIÓN ENTRE CUATRO ESPECIES DE LAPAS (PATELLA SPP.) REVELADA POR LOCI ALOENZIMÁTICOS. - La hibridación entre distintas especies de lapas del género Patella siempre ha sido un tema polémico. Aunque un estudio anterior de aloenzimas presenta una elevada diferenciación y ausencia de hibridación entre Patella vulgata Linnaeus, 1758, Patella depressa Pennant, 1777 y Patella ulyssiponensis Gmelin, 1791 en la costa inglesa, el reciente descubrimiento de un individuo de $P$. vulgata con un haplotipo mitocondrial de $P$. depressa ha planteado nuevas dudas respecto a este tema. Para estudiar más detalladamente la posibilidad de hibridación entre especies de lapas y su diferenciación genética se han analizado 10 loci aloenzimáticos por electroforesis en gel de almidón, en muestras de $P$. ulyssiponensis, $P$. depressa, $P$. vulgata y Patella rustica Linnaeus, 1758, de la costa atlántica de la península Ibérica. Los resultados así obtenidos evidencian la gran diferenciación existente entre especies, las cuales se separan claramente en distintos grupos con un algoritmo de agrupamiento Bayesiano. La ausencia de evidencias significativas de hibridación entre cualquiera de las cuatro especies estudiadas no permite respaldar la hipótesis de hibridación entre $P$. depressa y $P$. vulgata en su área de simpatría. La identificación de dos grupos simpátricos en $P$. vulgata puede estar relacionada con el desequilibrio de Hardi-Weinberg en el locus MPI. La elevada variabilidad intra-específica exhibida por los loci analizados puede convertirlos en herramientas de elevado interés para el análisis de la estructura poblacional y la identificación de reservorios.

Palabras clave: Patellidae, Patella spp., electroforesis en gel de almidón, aloenzimas, hibridación, polimorfismo genético.

\section{INTRODUCTION}

The genus Patella belongs to the order Patellogastropoda and is distributed across rocky shores of the northeast Atlantic and the Mediterranean and Black Seas (see review in Ridgway et al., 1998). Historically, the species identification in this genus was based on morphological 
characters such as the colour of the foot and paleal tentacles, the colour and shape of the internal and external parts of the shell and the radular teeth morphology (Fischer-Piette and Gaillard, 1959). However, most of these characters show high morphological plasticity and are influenced by environmental conditions (Branch, 1981), leading to an overlap of states between different species (see for example Mauro et al., 2003). This complex pattern of morphological variation has been the cause of great disagreements on the taxonomy of this genus, with different authors considering different numbers of species depending on the set of characters used (see reviews in Christiaens, 1973; Titselaar, 1998 and Gaffney, 1980).

The possibility of hybridisation between species is another contentious issue in the taxonomy of the genus Patella. Some authors consider the occurrence of individuals with intermediate characteristics as the result of hybridisation (Fretter and Graham, 1976), while others argue that the putative "hybrids" result from the accentuated morphological plasticity of these species (Titselaar, 1998). A recent study based on two mitochondrial genes (Koufopanou et al., 1999) revealed a haplotype in Patella vulgata Linnaeus, 1758 very similar to those found in Patella depressa Pennant, 1777. This haplotype was later confirmed to belong to the clade of $P$. depressa and to be very distinct from those found in P. vulgata (Sá-Pinto et al., 2005). These results point either to the occurrence of a recent hybridisation event between the two species or to a sample misidentification or contamination in the work of Koufopanou et al. (1999). Although no signs of introgression between the two species were found by Sá-Pinto et al. (2005), the low sample size prevents a clear picture from being drawn from this study and highlights the need for further studies involving nuclear markers and larger sample sizes.

Allozymes are particularly suitable markers for analysing hybridisation between well-differentiated species. The low mutation rate makes these markers less susceptible to the confounding effects of homoplasia that was shown to affect faster evolving markers such as microsatellites (Estoup et al., 1995). Although other nuclear markers such as SNPs and nuclear sequences are becoming increasingly used, an initial scan of large amounts of the genome is needed, which may be a difficult task in species for which little genomic information is available. Allozymes have already been successfully used to discriminate species of the genus Patella, to study taxonomic problems within the genus (Gaffney, 1980; Côrte-Real et al, 1992; Sella et al., 1993; Côrte-Real et al, 1996a and 1996b; Weber et al., 1997; Weber and Hawkins, 2002; Mauro et al., 2003; Weber and Hawkins, 2005) and to study genetic substructuring within species (Hurst and Skibinski, 1995; Weber et al., 1998; Mauro et al. 2001; Weber and Hawkins, 2005 and 2006). These markers have also been used to study hybridisation between P. depressa, Patella ulyssiponensis Roding 1798 and P. vulgata in southwest England (Gaffney, 1980). In this study, high differentiation and no evidence of hybridisation between the three species was found. However, these species also occur in sympatry on the Atlantic shores of the Iberian Peninsula, where ecological features differ from those found in England, as is shown by the occurrence of Patella rustica Linnaeus, 1758 in the former area but not in the latter (for P. rustica distribution see review in Lima et al., 2006). These different ecological conditions could favour hybridisation or hybrid survival in the Iberian Peninsula but not in England, as has already been shown to occur in other animal species (Borge et al. 2005). This would explain the findings of introgressed mtDNA despite the apparent absence of hybridisation in England.

To test this hypothesis we analysed ten allozyme loci in Iberian populations of $P$. vulgata and $P$. depressa. Additionally, we studied Iberian populations of P. ulyssiponensis and P. rustica to check for hybridisation between all intertidal limpet species present in this area.

\section{MATERIAL AND METHODS}

\section{Data collection}

Three locations from the western coast of Portugal were sampled for P. vulgata, P. ulyssiponensis and $P$. depressa. Since $P$. rustica is very rare in the northern part of this area (see Lima et al., 2006), samples of this species were only collected from two locations in the southern part of this range. The sampling locations are shown in Figure 1.

Individual limpets were identified through the analysis of morphological characters (Christiaens, 1973). All specimens were taken alive to the laboratory where they were immediately dissected and stored at $-80^{\circ} \mathrm{C}$. 


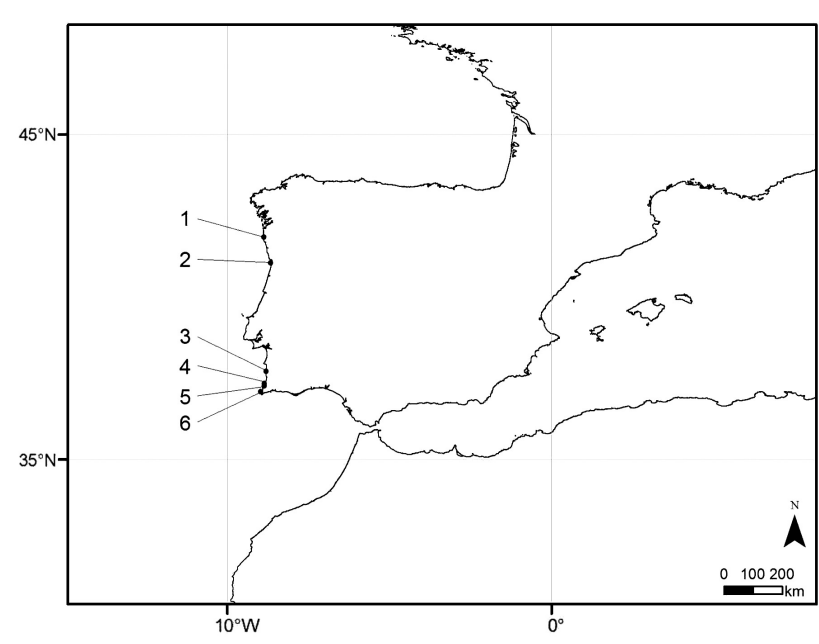

FIG. 1. - Map of the Iberian Peninsula showing the sampling sites. 1) Moledo, 2) Aguda, 3) Vila Nova de Milfontes, 4) Monte Clérigo, 5) Arrifana, 6) Castelejo.

To obtain tissue extracts, a portion of the foot muscle was ground in about the same volume of homogenising buffer (Weber et al., 1998). The tissue cells were then lysated by sonication, during which homogenates were submerged in ice to avoid heat inactivation of enzymes. A centrifugation was performed at $17530 \mathrm{~g}$ for 15 minutes at $-4^{\circ} \mathrm{C}$. The supernatants were collected and treated with a final concentration of $28 \mathrm{mM}$ of DTT for one hour at $37^{\circ} \mathrm{C}$. Samples were then applied to a $15 \%(\mathrm{w} / \mathrm{v})$ starch gel in a 1:1 sephadex medium. Electrophoreses were performed at $8^{\circ} \mathrm{C}$ for 16 to 17 hours at 5.5 to $6.0 \mathrm{~V} / \mathrm{cm}$.

From the enzymatic systems tested, ten loci showed polymorphism and a consistent pattern of bands and were selected for subsequent analysis: Malate dehydrogenase (MDH, EC: 1.1.1.37), Malic enzyme (ME, EC: 1.1.1.40), Isocitrate dehydrogenase (IDH, EC: 1.1.1.42), 6-Phosphogluconate dehydrogenase (PGD, EC: 1.1.1.44), Nucleoside phosphorylase (NP, EC: 2.4.2.1), Glutamateoxaloacetate transaminase (GOT, EC: 2.6.1.1), Phosphoglucomutase (PGM, EC: 2.7.5.1), Peptidase D (PEP D, EC: 3.4.13.9), Mannose phosphate isomerase (MPI, EC: 5.3.1.8 ) and Glucose phosphate isomerase (GPI, EC: 5.3.1.9). Three different buffer systems were used: i) citrate- $\mathrm{NaOH}-\mathrm{His} / \mathrm{HCl}, \mathrm{pH}$ 6.0 (Ferrand and Amorim, 1990) for MDH, IDH, NP, GOT, PGM and GPI; ii) tris- $\mathrm{NaH}_{2} \mathrm{PO}_{4}, \mathrm{pH} 7.6$ (Branco et al., 1999) for ME and PEPD; and iii) triscitrate, pH 7.6 (Amorim and Siebert, 1982) for MPI and PGD. The enzymatic detection of all loci was carried out using the staining methods described by Harris and Hopkinson (1976). For PepD the sub- strate used was phenylalanyl-proline. Staining solutions were mixed with $20 \mathrm{ml}$ of agarose $10 \%(\mathrm{w} / \mathrm{v})$ and applied to the gels.

\section{Data analyses}

Allelic frequencies, expected heterozygosity $(\mathrm{He})$, observed heterozygosity $(\mathrm{Ho})$, proportion of polymorphic loci at 0.99 polymorphism criterion $\left(\mathrm{P}_{99}\right)$ and Fis values were calculated using the GENETIX software package (Belkhirt, 1996). The same program was used to test whether the Fis values obtained for each locus and each species were significantly different from those expected by chance in a population at Hardy-Weinberg equilibrium (HW). Exact-tests (Raymond and Rousset, 1995a) available on the GENEPOP software (v.3.1b; Raymond and Rousset, 1995b) were performed to test for significant deviations to HW and Linkage equilibria, for the occurrence of heterozygote deficiency and for genic and genotypic differentiation between samples of each species.

The values of allelic richness for each locus were calculated for a sample size of 42 genes $\left(\mathrm{A}_{(42)}\right)$ using the CONTRIB software (Petit et al., 1998) and mean values of allelic richness for each species were calculated manually.

To assess the reliability of the genetic markers to discriminate between the four species and to infer the proportion of each individual's genome assigned to each species, we used the Bayesian clustering approach implemented in the BAPS v4.14 program (Corander and Marttinen, 2006). This methodology assigns samples to clusters minimising HW and linkage disequilibria (Corander et al., 2003) and calculates the admixture observed in each individual's genome. It starts by estimating the most likely number of clusters $(\mathrm{K})$ present in a given dataset, by integrating over all possible $\mathrm{K}$ (until a maximum K provided by the user). The proportion of each individual's genome assigned to each cluster is calculated in a second step together with the probability of the admixture observed in a given individual. This last value consists of the proportion of reference individuals simulated for the cluster to which a given individual is initially assigned, with a lower or equal proportion of their genome assigned to that cluster.

For the present analysis, 10 runs were performed with 20 replicates each, with maximum K set to 15 clusters. The admixture proportions were then calculated using the clusters previously inferred. To 
check whether the admixture results were consistent, 10 different runs were performed, with 10000 iterations, 500 simulated reference individuals and 20 iterations for reference individuals. For each run, the minimum number of individuals in each cluster for it to be considered in admixture analyses was set to one.

GENDIST in the PHYLIP software package (v.3.5; Felsenstein, 1993) was used to calculate Nei's standard genetic distance (Nei, 1972) between species.

\section{RESULTS}

\section{Genetic variability}

The estimated allelic frequencies and number of individuals analysed per location and per locus are shown in Appendix 1.

Observed electrophoretic patterns conformed to the simple model of inheritance of codominant alleles in autosomal loci coding for proteins of monomeric (MPI and PGM), dimeric (PGD, PEPD, IDH, MDH, GOT and GPI), trimeric (NP) and tetrameric (ME) quaternary structures. Due to the difficulties involved in the captive breeding of Patella limpets, no progeny testing was carried out to confirm the mode of inheritance. All loci were in agreement with HW expectations ( $\mathrm{p}>0.01$ ), with the exception of MPI in P. vulgata in Moledo and Monte Clérigo, $(\mathrm{p}<0.01)$. The deviations from HW equilibrium observed in $P$. vulgata were due to a significant deficit of heterozygotes $(\mathrm{p}<0.01)$. P. vulgata is also the only species that shows Fis values significantly different from zero (Table 1). None of the species showed significant deviations from linkage equilibrium between any pair of loci across all populations (p>0.01). With the exception of MPI in P. vulgata, no genic or genotypic differentiations were observed between the locations sampled for each species ( $>0.01)$.

All loci were polymorphic at the interspecific level, with different degrees of polymorphism found at the intraspecific level. In P. depressa fixed alleles were detected at loci MPI, ME and IDH, with the remaining loci having between two (MDH and GOT) and eight alleles (in PGM). For P. vulgata, only one allele was found at the MDH and GOT loci. The number of alleles found at the other loci varied from two, in IDH, to eight, in PGM. In $P$.
TABLE 1. - Values of expected heterozygosity (He), observed heterozygosity (Ho), proportion of polymorphic loci using 0.99 criterion $\left(\mathrm{P}_{99}\right)$, allelic richness for a sample size of 42 genes $\left(\mathrm{A}_{(42)}\right)$ and Fis (Weir and Cockerham, 1984) obtained for each species. * Value of Fis significantly higher than expected at $(\mathrm{p}<0.01)$.

\begin{tabular}{lccccc}
\hline & $\mathrm{He}$ & $\mathrm{Ho}$ & $\mathrm{P}_{99}$ & $\mathrm{~A}_{(42)}$ & Fis \\
\hline $\begin{array}{l}\text { Patella depressa } \\
\text { Patella vulgata }\end{array}$ & 0.07 & 0.08 & 0.50 & 1.96 & -0.03 \\
Patella ulyssiponensis & 0.15 & 0.12 & 0.80 & 2.22 & $0.21^{*}$ \\
Patella rustica & 0.23 & 0.80 & 2.51 & 0.03 \\
& 0.19 & 0.18 & 0.70 & 2.02 & 0.06 \\
\hline
\end{tabular}

ulyssiponensis only PGD showed a unique allele, with the other loci having between two (IDH, MPI and NP) and six alleles (GPI, PGM and PEP D). In $P$. rustica a fixed allele was found in IDH, GOT and $\mathrm{MDH}$, the remaining loci showing a maximum of four alleles (PGM and NP). The values of He, Ho, $\mathrm{A}_{(42)}$ and $\mathrm{P}_{99}$ obtained for each species are shown in Table 1.

A total of 89 alleles were detected across all species and loci. From these 89 alleles, 66 were species-specific, and among the 23 shared alleles 10 were shared only by two species, with a frequency of less than 0.1 in at least one of them (see Appendix 1). Two loci were shown to be diagnostic between species (MPI and MDH), one of which (MPI) was already reported by Gaffney (1980) for P. vulgata, $P$. depressa and $P$. ulyssiponensis from southwest England and by Sella et al. (1993) for P. ulyssiponensis, P. rustica and Patella caerulea Linnaeus, 1758 from the Mediterranean Sea.

\section{Bayesian clustering analysis and admixture}

All the runs of BAPS converged to the same result concerning the most probable number of clusters present in the data set, although three different solutions were recovered for the assignment of individuals to each of these clusters. According to these results, the most probable number of clusters in the dataset was five, three of them corresponding to individuals morphologically identified as $P$. depressa, $P$. ulyssiponensis and P. rustica and the remaining two corresponding to individuals identified as $P$. vulgata. The three different outcomes obtained corresponded to alternative ways of grouping $P$. vulgata individuals into these two clusters. The solution with the highest marginal likelihood (log of marginal likelihood $=-2175.0523$ ) was chosen to perform subsequent admixture analysis. All ten runs performed for inferring the admixture proportions 


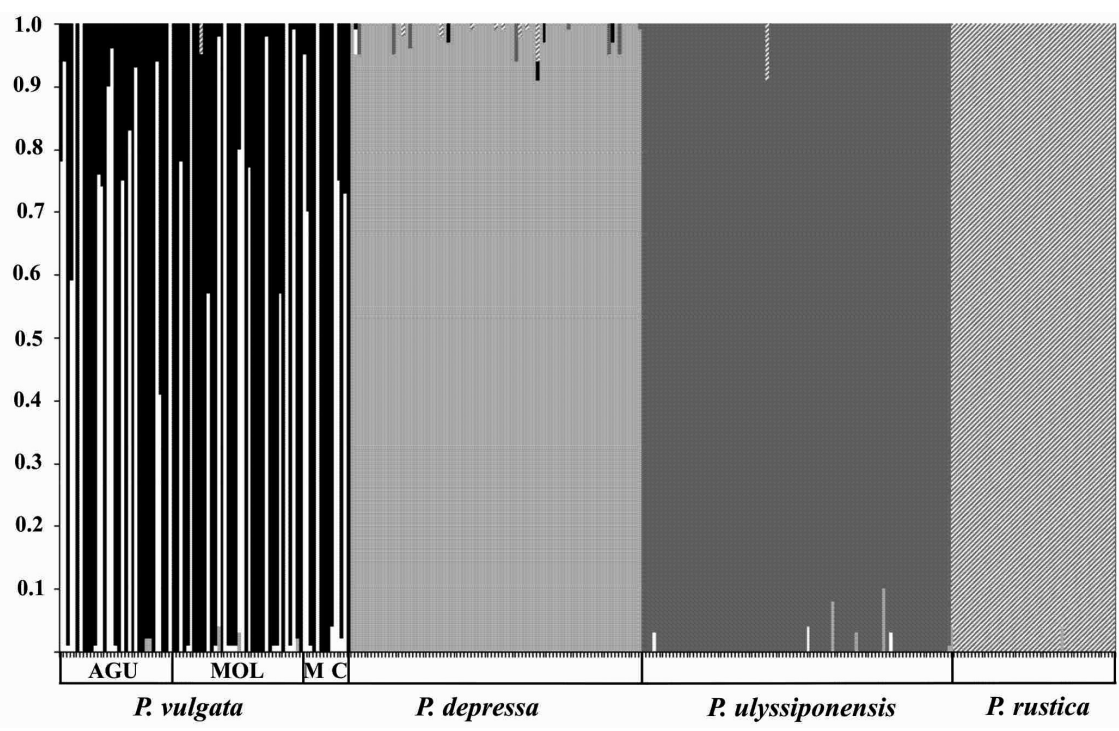

FIG. 2. - Plot of the percentage of each individual's genome assigned to a given species according to BAPS results. Black - Patella vulgata PvA cluster; white - P. vulgata PvB cluster; light grey - Patella depressa cluster; dark grey- Patella ulyssiponensis cluster; striped grey Patella rustica cluster. Morphological identification of the individuals and sampling locations of $P$. vulgata are indicated below the plots AGU - Aguda, Mol - Moledo, MC - Monte Clérigo.

returned similar results, with maximum variations of 0.01 in the proportion of each individual's genome assigned to a given species and in the admixture probability inferred for each individual. For this reason, we focused only on one of these runs. With the exception of $P$. vulgata, all individuals morphologically identified as belonging to a species clustered together with no less than $90 \%$ of their nuclear genome assigned to that species (Fig. 2). The individuals morphologically identified as $P$. vulgata were divided into two clusters, PvA and PvB, both present in the three locations. PvA was the most frequent cluster in Moledo (proportion of individuals mostly assigned to PvA was 0.7) but the two clusters were almost equally common in Aguda and Monte Clérigo (the proportions of individuals mostly assigned to PvA were 0.55 and 0.5 respectively, see Figure 2). Although PvB is in agreement with $\mathrm{HW}$ expectations for all loci ( $\mathrm{p}>0.01)$, PvA still exhibited significant deviations from HW expectations for MPI $(p<0.01)$, due to a significant deficit of heterozygotes $(\mathrm{p}<0.01)$. PvA and PvB showed significant genic and genotypic differentiation for MPI and PGD loci $(\mathrm{p}<0.01)$.

If the two clusters obtained within P. vulgata were joined into a single one, the vast majority of individuals analysed had a minimum of $95 \%$ of their genome assigned to the correct species $(98 \%$ of $P$. depressa samples, $100 \%$ of $P$. vulgata, $97 \%$ of $P$. ulyssiponensis and $100 \%$ of P. rustica). Only three individuals, morphologically identified as $P$. ulyssiponensis, had more than 5\% of their genome assigned to other species $(10 \%$ and $8 \%$ assigned to $P$. depressa in two individuals and $9 \%$ assigned to $P$. rustica in one individual), and none of them were successfully analysed for the locus $P G D$ which is diagnostic for $P$. ulyssiponensis. The individual with $9 \%$ of its genome assigned to $P$. rustica was also heterozygous for GOT\#2, which is a rare allele in $P$. ulyssiponensis but the most common one in P. rusti$c a$ and $P$. depressa. The remaining two individuals were both heterozygous for the allele PEPD\#3, which is the most common in P. depressa but is also present in P. vulgata and P. ulyssiponensis (estimated frequencies in P. ulyssiponensis between 0.2 and 0.3 , see Appendix A). Additionally, one of these two individuals was heterozygous for GOT\#2 and the other was heterozygous for GPI\#4, which are alleles that are rare in $P$. ulyssiponensis but common in $P$. depressa. Two individuals, morphologically identified as $P$. depressa, had less than $95 \%$ of their genome assigned to this species; one of these individuals had $6 \%$ of its genome assigned to $P$. ulyssiponensis, probably due to the presence of allele GOT\#3; the other individual had $6 \%$ of its genome assigned to $P$. rustica due to the presence of the allele PGD\#6. No individuals showed a significant probability of admixture between species, not even the individuals with less than $95 \%$ of their genome assigned to a single cluster $(\mathrm{p}>0.01)$.

Genetic distances between species are described in Table 2. These results suggest that $P$. ulyssiponen- 
TABLE 2. - Nei's standard genetic distance (Nei, 1972) between species, based on ten polymorphic allozyme loci.

\begin{tabular}{lcccc}
\hline & $P$. depressa & P. vulgata & P. ulyssiponensis & P. rustica \\
\hline P. depressa & 0 & 4.986 & 1.379 & 1.442 \\
$P$. vulgata & - & 0 & 5.469 & 2.481 \\
$P$. ulyssiponensis & - & - & 0 & 1.634 \\
$P$. rustica & - & - & - & 0 \\
\hline
\end{tabular}

sis and P. depressa are the most closely related taxa, while $P$. vulgata and $P$. ulyssiponensis seem to be the most differentiated ones.

\section{DISCUSSION}

\section{Hybridisation between species}

Although allozymes are becoming "out of fashion", their use may provide important answers to problems like species identification and the study of hybridisation. Our survey of ten allozyme loci showed high differentiation between the four limpet species, $P$. vulgata, $P$. depressa, $P$. rustica and $P$. ulyssiponensis, with no signs of gene flow between any of them. These results are in agreement with those of Gaffney (1980) and further extend these findings to $P$. rustica. Therefore it seems highly unlikely that the observation of a $P$. depressa mtDNA haplotype in P. vulgata (Koufopanou et al., 1999 see also Sá-Pinto et al., 2005) could be the outcome of gene flow between these species.

According to the results of BAPS, the great majority of individuals had more than $95 \%$ of their genome assigned to the species to which they were assigned according to morphological characters. Some individuals of $P$. depressa and P. ulyssiponensis had between 90 and $95 \%$ of their genome assigned to these taxa, due to the occurrence of shared alleles between species. The finding of shared alleles between species can be explained by maintenance of ancestral alleles, homoplasia or hybridisation between species. Some of the shared alleles, like GOT\#2 and PEPD\#3, occur in two or more species with frequencies higher than $20 \%$ in at least two of them, suggesting the maintenance of ancestral polymorphism as the most probable hypothesis. Shared alleles may also represent homoplasic electromorphs that resulted from the combination of different net charges and sizes for different alleles (Ramshaw, 1979). Although we cannot reject the occurrence of rare events of hybridisation, the high divergence between species revealed by mtDNA (Sá-Pinto et al. 2005), and the absence of first and second generation hybrids evidenced in the present survey and that of Gaffney (1980), make hybridisation the least likely explanation for the occurrence of shared alleles.

Although there is a considerable overlap of the spawning seasons of $P$. vulgata and $P$. depressa on the Portuguese coast (Guerra and Gaudêncio, 1986), no signs of hybridisation were found in the present work. Since the distribution ranges of P. vulgata and $P$. depressa only overlap between southern England and southern Portugal, the present study and the one by Gaffney (1980) have almost covered their entire overlapping area, thus reducing the probability of different environmental conditions favouring the existence of hybrids in one place relative to the other. Although we cannot completely rule out the possibility that a very rare event of hybridisation between these two species had resulted in mtDNA introgression, the result of Koufopanou et al. (1999) is, according to both mtDNA and allozymes (SáPinto et al. 2005; Gaffney 1980; present work), most likely explained by a sample misidentification or laboratorial contamination, as previously suggested by Sá-Pinto et al. (2005).

Despite the increasing use of DNA sequences in phylogenies, the use of allozymes as complementary data has some major advantages since allozyme data are usually composed of multiple unlinked nuclear loci. Therefore, phylogenies inferred from multiple allozyme loci are less frequently misled by mismatches between gene trees and species trees than phylogenies based on a single DNA locus (Wiens, 2000). According to Nei's standard genetic distances (Nei, 1972, see Table 2), P. ulyssiponensis and $P$. depressa are the most closely related species and $P$. vulgata is the most differentiated one. P. rustica is intermediate and closer to P. depressa and P. ulyssiponensis than to $P$. vulgata. The closer phylogenetic relationship between $P$. ulyssiponensis and $P$. depres$s a$ is in agreement with the tree obtained with three mtDNA genes (12s, 16s and COI) and disagrees with that obtained only with COI (Sá-Pinto et al, 2005, Mauro et al., 2003). However, the COI fragment analysed was shown to be saturated at this level of divergence (Sá-Pinto et al, 2005), thus increasing the reliability of the phylogeny inferred from the three mtDNA genes and supported by the genetic distances estimated from allele frequencies in allozyme loci. 


\section{Intraspecific variability and genetic substructuring}

All loci were polymorphic between species but their intraspecific variability changed from species to species, with different loci being polymorphic in different species. This information may provide important clues for choosing loci to investigate population structure within species, for studying population evolutionary history or even for identifying different genetic stocks for management purposes. Although the electrophoretic methods and loci analysed were not exactly the same, the values of expected heterozygosity obtained for $P$. depressa, $P$. vulgata and $P$. rustica were generally lower than those reported in previous studies (Gaffney, 1980; Sella et al. 1993; Hurst and Skibinski, 1995; CorteReal et al., 1996a and 1996b; Weber and Hawkins, 2006), while for P. ulyssiponensis they fell within the range described in other works (Gaffney, 1980; Lavie et al., 1987; Sella et al. 1993; Corte-Real et al., 1992; Weber et al., 1998; Weber and Hawkins, 2005). The pattern of higher diversity in P. ulyssiponensis and lower diversity in $P$. depressa is also in agreement with the results of Gaffney (1980).

The absence of significant genic and genotypic differentiation between sampling locations (with the exception of MPI in P. vulgata) suggests the occurrence of high gene flow across the sampled area for the four species. The presence of a pelagic larval stage and the relatively small geographic distances between locations may account for the high homogeneity observed.

Strong HW disequilibrium was found at $P$. vulgata sampling locations, due to significant deficit of heterozygotes. Numerous hypothesis have been put forward to explain the deficit of heterozygotes observed in limpet species, such as misinterpretation of gels, aneuploidy, null alleles, selection, inbreeding and the Wahlund effect (see review in Weber and Hawkins, 2006). We believe that the observed deficit of heterozygotes does not result from misinterpretation of gels and the high excess of homozygotes also fails to support the hypothesis of aneuploidy. This left us with three hypotheses to explain the observed HW disequilibrium: $i$ ) inbreeding and /or the Wahlund effect; $i$ ) the occurrence of a null allele and iii) selection acting in MPI.

The two clusters recovered within P. vulgata may indicate the existence of two differentiated forms within this species, occurring at all sampling loca- tions. Restricted gene flow between these two forms is supported by the significant differentiation observed between them not only in MPI but also in PGD. According to these results, inbreeding and the Wahlund effect would be the most likely explanations for the deficit of heterozygotes detected in MPI. However, only one of the two clusters recovered by BAPS was in agreement with HW expectations for MPI, suggesting that the existence of these two subpopulations within $P$. vulgata does not fully explain the observed lack of HW equilibrium. Thus, alternative hypotheses of selection acting on MPI or the occurrence of a null allele cannot be ruled out.

The existence of a null allele in MPI could explain the observed heterozygote deficiency, but the monomeric structure of this enzyme makes it more difficult to detect this kind of allele than in those enzymes where heterodimers are present. In a survey involving autossomal and X-linked loci of Drosophila melanogaster, Voelker et al. (1980) found that null alleles were present in 13 out of the 25 loci. All the null alleles found in this study were present in such low frequencies that they were unable to cause a significant heterozygote deficit (maximum frequency observed $0.9 \%$ ). In fact, null alleles are usually found in low frequencies due to expected lower viability of their carrier individuals. However, these alleles may achieve higher frequencies, depending on the importance of the enzyme function and on enzyme redundancy (Voelker et al., 1980).

Another possible explanation for the observed heterozygote deficiency in MPI is the occurrence of different selective pressures across the beach in this locus. In Semibalanus balanoides (Schmidt and Rand, 1999) MPI was shown to be under strong selection with different alleles being selected in different areas of the beach. These authors argued that organisms that ingest high amounts of algae (which are rich in mannose) and are exposed to thermal and anaerobic stress may be a target of selection at this enzyme. In fact, like other limpets, $P$. vulgata feeds on algae and, due to its position in the intertidal zone, is exposed to thermal and anaerobic stress in each tidal cycle making this species a potential candidate for selection in MPI.

To further investigate the causes of the HW disequilibrium observed in MPI and to distinguish between alternative hypotheses, additional studies are necessary with a sampling scheme like that used by Schimdt and Rand (1999) and a more intensive locus screening. 


\section{ACKNOWLEDGMENTS}

We thank Pedro Ribeiro, António Múrias, Pedro Cardia and Catarina Pinho for their help during sampling and for useful comments and suggestions on this manuscript. Figure 1 was kindly provided by Pedro Tarroso. We would also like to thank two anonymous referees as well as the editors of Scientia Marina for their useful comments and suggestions.

This work was supported by the FCT (Fundação para a Ciência e Tecnologia), through the project POCTI/BSE/42300/2001. Alexandra Sá Pinto and Madalena Branco were supported by the FCT grants SFRH/BD/7090/2001 and SFRH/BPD/5610/2001, respectively.

\section{REFERENCES}

Amorim, A. and G. Siebert. - 1982. Glutamate pyruvate transaminase, esterase $\mathrm{D}$, glyoxalase I, and phosphoglucomutase 1 polymorphisms in Porto district (Portugal). Hum. Hered., 32: 298.

Belkhirt K. - 1996. GENETIX, logiciel sous WindowsTM pour la génétique des populations. Laboratoire Génome et Populations, CNRS UPR 9060, Université de Montpellier II, Montpellier (France).

Branch, G. - 1981. The Biology of Limpets: Physical factors, energy flow and ecological interactions. Oceanogr. Mar. Biol.. Аппи. Rev., 19: 235-280

Branco, M., J. Machado and N. Ferrand. - 1999. Extensive genetic polymorphism of peptidases $\mathrm{A}, \mathrm{B}, \mathrm{C}$, and $\mathrm{D}$, in wild rabbit (Oryctolagus cuniculus) populations from the Iberian Peninsula. Biochem. Genet., 37: 237.

Borge, T., K. Lindroos, P. Nádvorník, A.-C Syvänen and G.-P. Saetre. - 2005. Amount of introgression in flycatcher hybrid zones reflects regional differences in pre- and post-zygotic barriers to gene exchange. J. Evol. Biol., 18: 1416-1424

Christiaens, J. - 1973. Révision du genre Patella (Mollusca, Gastropoda). Bull. Mus. Natl. Hist. Nat., 3, 182: 1305-1392.

Corander J, P. Waldmann and M. Sillanpää. - 2003. Bayesian analysis of genetic differentiation between populations. Genetics, 163: 367-374.

Corander, J. and P. Marttinen. - 2006. Bayesian identification of admixture events using multilocus molecular markers. Mol. Ecol., 15: 2833-2843.

Corte-Real, H., S. Hawkins and J. Thorpe. - 1992. Genetic confirmation that intertidal and subtidal morphs of Patella ulyssiponensis aspera Röding (Mollusca: Gastropoda: Patellidae) are conspecific. Arquipélago. Ciências da Natureza, 10: 55-66

Corte-Real, H., S. Hawkins and J. Thorpe. - 1996a. Population differentiation and taxonomic status of the exploited limpet Patella candei in the Macaronesian islands (Azores, Madeira, Canaries). Mar. Biol., 125: 141-152

Corte-Real, H., S. Hawkins and J. Thorpe. - 1996b. An interpretation of the taxonomic relationship between the limpets Patella rustica and P.piperata. J. Mar. Biol. Ass. U.K., 76: 717-732.

Estoup, A., C. Tailliez, J-M. Cornuet and M. Solignac. - 1995. Size homoplasy and mutational processes of interrupted microsatellites in two bee species, Apis mellifera and Bombus terrestris (Apidae). Mol. Biol. Evol., 12(6): 1074-1084

Felsenstein, J. - 1993. PHYLIP (Phylogeny Inference Package) Version 3.5.c. Distributed by the author. Seattle. University of Washington.

Ferrand, N. and A. Amorim. - 1990. Genetic polymorphism of ?aminolaevulinic acid dehydratase (E.C. 4.2.1.24, ALAD) in the domestic rabbit. Anim. Genet., 21: 217.

Fischer-Piette, E. and J. Gaillard. - 1959. Les Patelles au long des cotes Atlantiques Ibériques et nord Marocaines. Journal de Conchyliologie, 99: 135-200.

Fretter, V. and A. Graham. - 1976. The Prosobranch Molluscs of Britain and Denmark. J. Molluscan Stud. (Suppl. 1): 1-37

Gaffney, P. - 1980. On the number of Patella species in SouthWest England. J. Mar. Biol. Ass. U. K., 60: 565-574.

Guerra, M. and M. Gaudencio. - 1986. Aspects of the ecology of Patella spp. on the Portuguese coast. Hydrobiologia, 142: 57-69.

Harris, H. and D. Hopkinson. - 1976. Handbook of Enzyme Electrophoresis in Human Genetics. North Holland, Amsterdam.

Hurst, C. and D. Skibinski. - 1995. Comparison of allozyme and mitochondrial DNA spatial differentiation in the limpet Patella vulgata. Mar. Biol., 122: 257-263

Koufopanou, V., D. Reid, S. Ridgway and R. Thomas. - 1999. A molecular phylogeny of the Patellid limpets (Gastropoda: Patellidae) and its implications for the origins of their antitropical distribution. Mol. Phylogenet. Evol., 11: 138-156

Lavie, B., R. Noy and E. Nevo. - 1987. Genetic variability in the marine gastropods Patella coerulea and Patella ulyssiponensis: patterns and problems. Mar. Biol., 96: 367-370.

Lima, F.P., N. Queiroz, P.A. Ribeiro, S.J. Hawkins and A.M. Santos. - 2006. Recent changes in the distribution of a marine gastropod, Patella rustica Linnaeus, 1758, and their relationship to unusual climatic events. J. Biogeogr., 33: 812-822.

Mauro, A., N. Parrinello and M. Arculeo. - 2001. Artificial environmental conditions can affect allozyme genetic structure of the marine Gastropod Patella caerulea. J. Shellfish Res., 20(3): 1059-1063.

Mauro, A., M. Arculeo and N. Parrinello. - 2003. Morphological and molecular tools in identifying the Mediterranean limpets Patella caerulea, Patella aspera and Patella rustica. J. Exp. Mar. Biol. Ecol., 295: 131-143

Nei, M. - 1972. Genetic distance between populations. Am. Nat., 106: 238-292.

Petit, R.J., A. El-Mousadik and O. Pons. - 1998. Identifying populations for conservation on the basis of genetic markers. Conserv. Biol., 12: 844-855.

Ramshaw, J., J. Coyne and R. Lewontin. - 1979. The sensitivity of gel electrophoresis as a detector of genetic variation. Genetics, 93: 1019-1037.

Raymond, M. and F. Rousset. - 1995a. An exact test for population differentiation. Evolution, 49: 1280-1283.

Raymond, M. and F. Rousset. - 1995b. GENEPOP (version 1.2): population genetics software for exact tests and ecumenicism. J. Hered., 86: 248-249

Ridgway, S., D. Reid, J. Taylor, G. Branch and A. Hodgson. 1998. A cladistic phylogeny of the family Patellidae (Mollusca:Gastropoda). Philos. Trans. R. Soc. Lond., B, 353: 1645-1671.

Sá-Pinto, A., M. Branco, D.J. Harris and P. Alexandrino. - 2005. Phylogeny and phylogeography of the genus Patella based on mitochondrial DNA sequence data. J. Exp. Mar. Biol. Ecol., 325: 95-110.

Sella, G., C.A. Robotti and V. Biglione. - 1993. Genetic divergence among three sympatric species of Mediterranean Patella (Archaeogastropoda). Mar. Biol., 115: 401-405.

Schmidt, P.S., and D.M. Rand. - 1999. Intertidal microhabitat and selection at MPI: interlocus contrasts in the northern acorn barnacle, Semibalanus balanoides. Evolution, 53: 135-146.

Titselaar, F. - 1998. A revision of the recent European Patellidae (Mollusca: Gastropoda). Vita Marina, 45(3-4): 21-62.

Voelker, R.A., C.H. Langley, A.J.L. Brown, S. Ohnishi, B. Dickson, E. Montgomery and S.C. Smith - 1980. Enzyme null alleles in natural populations of Drosophila melanogaster: Frequencies in a North Carolina population. Proc. Natl. Acad. Sci. USA, 77 (2): 1091-1095.

Weber, L.I., D.R. Gray, A.N. Hodgson and S.J. Hawkins. - 1997. Genetic divergence between the South African Helcion species and North-East Atlantic H. pellucidum (Mollusca: Patellogastropoda). J. Mar. Biol. Ass. U.K., 77: 1139-1150.

Weber, L., J. Thorpe, R. Santos and S. Hawkins. - 1998. Identification of the exploited limpets Patella aspera and $P$. cande $i$ at Madeira archipelago by allozyme electrophoresis. $J$. Shellfish Res., 17: 945-953

Weber, L.I. and S.J. Hawkins. - 2002. Evolution of the limpet Patella candei d'Orbigny (Mollusca: Patellidae) in Atlantic 
archipelagos: human intervention and natural processes. Biol.J. Linn. Soc., 77: 341-353.

Weber, L.I. and S.J. Hawkins. - 2005. Patella aspera and Patella ulyssiponensis: genetic evidence of speciation in the North-east Atlantic. Mar. Biol., 147: 153-162.

Weber, L.I. and S.J. Hawkins. - 2006. Allozymic differentiation among geographically distant populations of Patella vulgato (Mollusca, Patellogastropoda). Hydrobiologia, 553: 267-275.
Wiens, J.-2000. Reconstructing phylogenies from allozyme data: comparing method performance with congruence. Biol. J. Linn. Soc., 70: 613-632.

Scient. ed.: M. Pascual.

Received February 26, 2007. Accepted September 7, 2007.

Published online November 22, 2007.

APPENDIX 1. - Allelic frequencies and number of individuals analysed for ten protein loci in three locations for Patella vulgata, P. depressa and P.ulyssiponenesis and two for P. rustica. Mol: Moledo; Agu: Aguda; VNM: Vila Nova de Milfontes; MC: Monte Clérigo; Cas: Castelejo; Ari: Arrifana. The number of individuals analysed per locus per location and the name of each locus are written in bold. * represents alleles that were not found in that species.

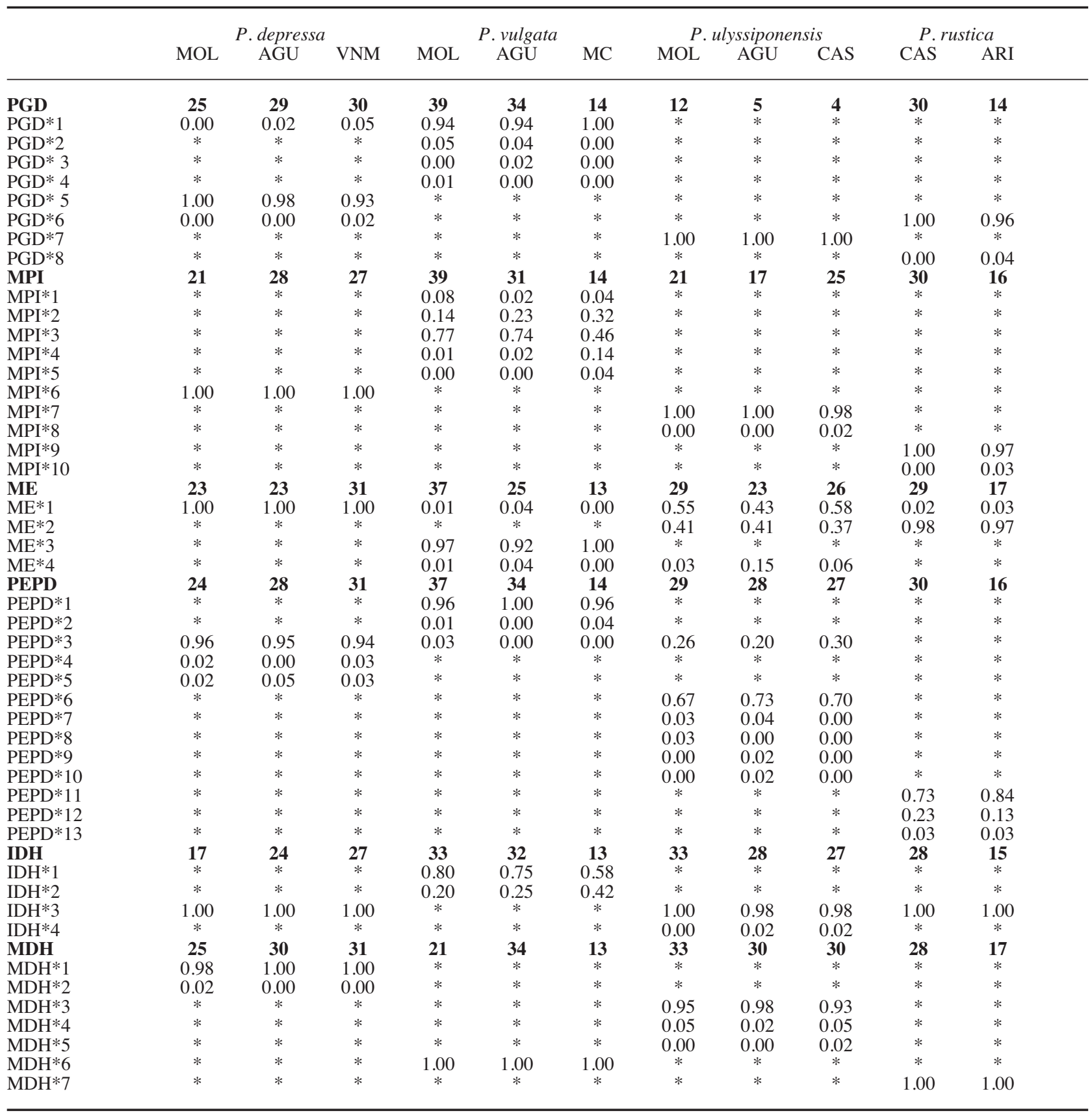


810 • A. SÁ-PINTO et al.

APPENDIX 1 (cont.). - Allelic frequencies and number of individuals analysed for ten protein loci in three locations for Patella vulgata, $P$. depressa and P.ulyssiponenesis and two for P. rustica. Mol: Moledo; Agu: Aguda; VNM: Vila Nova de Milfontes; MC: Monte Clérigo; Cas: Castelejo; Ari: Arrifana. The number of individuals analysed per locus per location and the name of each locus are written in bold. * represents alleles that were not found in that species.

\begin{tabular}{|c|c|c|c|c|c|c|c|c|c|c|c|}
\hline & & P. depressa & & & P. vulgat & & & yssipon & & $P . r$ & $i c a$ \\
\hline & MOL & AGU & VNM & MOL & AGU & $\mathrm{MC}$ & MOL & $\mathrm{AGU}$ & CAS & CAS & ARI \\
\hline GOT & 25 & 30 & 31 & 36 & 30 & 13 & 29 & 30 & 29 & 30 & 12 \\
\hline GOT*1 & $*$ & $*$ & $*$ & 1.00 & 1.00 & 1.00 & $*$ & $*$ & $*$ & $*$ & $*$ \\
\hline GOT*2 & 1.00 & 0.98 & 1.00 & $*$ & $*$ & $*$ & 0.00 & 0.03 & 0.00 & 1.00 & 1.00 \\
\hline GOT*3 & 0.00 & 0.02 & 0.00 & * & $*$ & $*$ & 0.93 & 0.87 & 0.97 & $*$ & $*$ \\
\hline GOT*4 & $*$ & $*$ & $*$ & $*$ & $*$ & $*$ & 0.07 & 0.08 & 0.03 & $*$ & $*$ \\
\hline GOT*5 & $*$ & * & * & * & $*$ & $*$ & 0.00 & 0.02 & 0.00 & * & $*$ \\
\hline NP & 24 & 24 & 28 & 33 & 29 & 13 & 27 & 29 & 29 & 26 & 10 \\
\hline NP*1 1 & 0.02 & 0.00 & 0.00 & 1.00 & 1.00 & 0.92 & $*$ & * & $*$ & $*$ & $*$ \\
\hline $\mathrm{NP} * 2$ & $*$ & $*$ & $*$ & 0.00 & 0.00 & 0.04 & $*$ & $*$ & $*$ & $*$ & $*$ \\
\hline $\mathrm{NP} * 3$ & * & * & $*$ & 0.00 & 0.00 & 0.04 & $*$ & $*$ & $*$ & $*$ & $*$ \\
\hline NP*4 & 0.92 & 1.00 & 1.00 & $*$ & $*$ & $*$ & $*$ & $*$ & $*$ & * & $*$ \\
\hline $\mathrm{NP} * 5$ & 0.04 & 0.00 & 0.00 & $*$ & $*$ & * & 0.96 & 0.97 & 0.95 & * & $*$ \\
\hline $\mathrm{NP} * 6$ & 0.02 & 0.00 & 0.00 & $*$ & $*$ & $*$ & $*$ & $*$ & $*$ & $*$ & $*$ \\
\hline NP*7 & $*$ & $*$ & $*$ & * & $*$ & $*$ & 0.04 & 0.03 & 0.05 & $*$ & $*$ \\
\hline $\mathrm{NP} * 8$ & $*$ & $*$ & $*$ & $*$ & $*$ & $*$ & $*$ & $*$ & $*$ & 0.54 & 0.75 \\
\hline NP*9 & $*$ & $*$ & $*$ & * & $*$ & $*$ & $*$ & $*$ & $*$ & 0.23 & 0.10 \\
\hline NP*10 & $*$ & * & * & * & $*$ & $*$ & $*$ & * & $*$ & 0.06 & 0.00 \\
\hline NP*11 & * & $*$ & $*$ & $*$ & $*$ & $*$ & $*$ & $*$ & $*$ & 0.17 & 0.15 \\
\hline PGM & 25 & 27 & 31 & 38 & 34 & 12 & 29 & 30 & 28 & 30 & 17 \\
\hline $\mathrm{PGM}^{* 1} 1$ & $*$ & $*$ & $*$ & 0.03 & 0.04 & 0.00 & 0.16 & 0.17 & 0.09 & 0.03 & 0.03 \\
\hline $\mathrm{PGM}^{* 2} 2$ & * & * & $*$ & 0.82 & 0.79 & 0.75 & 0.02 & 0.02 & 0.02 & $*$ & $*$ \\
\hline $\mathrm{PGM}^{* 3}$ & $*$ & * & * & 0.13 & 0.12 & 0.13 & $*$ & $*$ & $*$ & * & * \\
\hline PGM*4 & * & * & $*$ & 0.01 & 0.01 & 0.00 & * & * & $*$ & $*$ & $*$ \\
\hline PGM*5 & $*$ & * & $*$ & 0.00 & 0.03 & 0.00 & $*$ & $*$ & $*$ & $*$ & $*$ \\
\hline $\mathrm{PGM}^{* 6} 6$ & $*$ & $*$ & $*$ & 0.00 & 0.00 & 0.08 & $*$ & $*$ & $*$ & $*$ & $*$ \\
\hline $\mathrm{PGM}^{* 7} 7$ & 0.02 & 0.00 & 0.00 & 0.00 & 0.00 & 0.04 & * & $*$ & $*$ & $*$ & $*$ \\
\hline $\mathrm{PGM}^{* 8} 8$ & 0.02 & 0.11 & 0.00 & 0.01 & 0.00 & 0.00 & 0.19 & 0.20 & 0.14 & 0.70 & 0.82 \\
\hline PGM*9 & 0.82 & 0.76 & 0.84 & $*$ & $*$ & $*$ & 0.40 & 0.35 & 0.41 & $*$ & $*$ \\
\hline PGM*10 & 0.12 & 0.13 & 0.11 & $*$ & $*$ & $*$ & $*$ & $*$ & $*$ & $*$ & $*$ \\
\hline $\mathrm{PGM}^{*} 11$ & 0.02 & 0.00 & 0.00 & $*$ & $*$ & $*$ & 0.24 & 0.25 & 0.34 & $*$ & $*$ \\
\hline $\mathrm{PGM}^{*} 12$ & 0.00 & 0.00 & 0.02 & $*$ & $*$ & $*$ & $*$ & $*$ & $*$ & $*$ & $*$ \\
\hline $\mathrm{PGM}^{*} 13$ & 0.00 & 0.00 & 0.02 & * & $*$ & $*$ & $*$ & $*$ & $*$ & $*$ & $*$ \\
\hline PGM*14 & 0.00 & 0.00 & 0.02 & * & $*$ & $*$ & $*$ & $*$ & $*$ & * & $*$ \\
\hline PGM*15 & $*$ & $*$ & $*$ & * & $*$ & * & 0.00 & 0.02 & 0.00 & * & $*$ \\
\hline $\mathrm{PGM}^{*} 16$ & $*$ & $*$ & $*$ & $*$ & $*$ & $*$ & $*$ & $*$ & $*$ & 0.20 & 0.15 \\
\hline PGM*17 & * & * & $*$ & * & $*$ & * & $*$ & $*$ & $*$ & 0.07 & 0.00 \\
\hline GPI & 25 & 27 & 31 & 29 & 27 & 14 & 29 & 29 & 29 & 30 & 17 \\
\hline GPI*1 & $*$ & $*$ & $*$ & 0.98 & 1.00 & 0.96 & $*$ & $*$ & $*$ & 0.73 & 0.65 \\
\hline GPI*2 & $*$ & * & $*$ & 0.02 & 0.00 & 0.00 & 0.00 & 0.00 & 0.03 & $*$ & $*$ \\
\hline GPI*3 & 0.02 & 0.04 & 0.06 & 0.00 & 0.00 & 0.04 & 0.00 & 0.00 & 0.02 & $*$ & $*$ \\
\hline GPI*4 & 0.92 & 0.96 & 0.85 & $*$ & $*$ & $*$ & 0.00 & 0.00 & 0.02 & $*$ & $*$ \\
\hline GPI*5 & 0.04 & 0.00 & 0.02 & $*$ & $*$ & $*$ & $*$ & $*$ & $*$ & * & $*$ \\
\hline GPI*6 & 0.02 & 0.00 & 0.00 & * & $*$ & $*$ & $*$ & * & $*$ & * & * \\
\hline GPI*7 & 0.00 & 0.00 & 0.03 & $*$ & $*$ & $*$ & 0.19 & 0.12 & 0.07 & * & $*$ \\
\hline GPI*8 & 0.00 & 0.00 & 0.03 & $*$ & $*$ & $*$ & 0.79 & 0.84 & 0.84 & $*$ & $*$ \\
\hline GPI*9 & $*$ & $*$ & $*$ & * & $*$ & $*$ & 0.02 & 0.03 & 0.02 & * & $*$ \\
\hline GPI*10 & $*$ & $*$ & $*$ & $*$ & $*$ & * & $*$ & $*$ & $*$ & 0.27 & 0.35 \\
\hline
\end{tabular}

